\title{
Cone Beam Ct Evaluations of Condyle Shape and Age-Related Associations of Articular Eminence Morphology in Female Tmd Patients
}

\author{
Kadın Tmd Hastalarında Kondil Şeklinin ve Artiküler Eminens Morfolojisi ile Yaşa Bağlı \\ Değişikliklerin İlişkisinin Kıbt ile Değerlendirilmesi
}

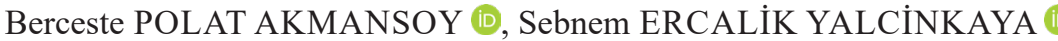

\begin{abstract}
Aim: The aim of this study was to assess condyle shape and the relationship between age-related associations and articular eminence (AE) inclination in a group of female patients with temporomandibular disorder (TMD).

Methods: CBCT images of 64 temporomandibular joints (TMJs) of 32 female TMD patients (18-45-year-old) were evaluated sagittally and coronally. Condyle shape was assessed visually and the inclination of AE was analyzed using with bestfit and top-roof methods. AE heights were also measured. The patients were grouped into two age groups: 18 to $30-$ and 31 to 45-year-old. Data were statistically analyzed with SPSS software using Mann-Whitney-U test.

Results: The most frequently observed condyle shape was flattened $(39,1 \%)$ in sagittal plane and triangular $(43,8 \%)$ in coronal plane. Triangular condyle shape was seen in $31.3 \%$ of condyles on coronal sections. No statistically significant differences were seen in two different age groups comparing AE inclination and height.

Conclusion: Triangular and flattened condyles were the most frequent condyle shape in female TMD patients. Although AE inclination was highest between the ages of 18-30, there was no statistical significance.
\end{abstract}

Keywords: Temporomandibular joint disorders, cone beam computed tomography, articular eminence inclination and height, condyle shape.

Berceste Polat AKMANSOY (四)

Specialist in Oral and Maxillofacial Radiology, Faculty of Dentistry, Department of Dentomaxillofacial Radiology, Istanbul, Turkey

bercestepolat@gmail.com

Sebnem ERCALİK YALCINKAYA

Professor, Marmara University, Faculty of Dentistry, Department of Dentomaxillofacial Radiology, Istanbul, Turkey

Submitted / Gönderilme: 24.12.2019 Accepted / Kabul: 27.12.2019
Öz

Amaç: $\mathrm{Bu}$ çalışmanın amacı temporomandibular eklem rahatsızlığı (TMR) olan bir grup kadın hastada kondil şeklinin ve artiküler eminens eğimi ile yaşa bağlı değişikliklerin ilişkisinin değerlendirilmesidir.

Metot: TMR'si bulunan yaşları 18-45 arasında değişen 32 kadın hastanın 64 adet temporomandibular ekleminin KIBT görüntüleri sagittal ve koronal kesitlerde değerlendirildi. Kondil şekli görsel olarak değerlendirildi ve artiküler eminens eğimi "best-fit" ve "top-roof" metotları ile belirlendi. Ayrıca artiküler eminens yüksekliği de ölçüldü. Hastalar 18-30 ve 31-45 olarak iki yaş grubuna ayrıldı. Verilerin kıyaslanmasının istatistiksel analizi için SPSS yazılımı ile uygulanan "Mann-Whitney-U test" kullanıldı.

Bulgular: Sagittal düzlemde en sık görülen kondil şekli düz (\% 39.1) iken koronal düzlemde üçgen (\% 43.8) olarak tespit edildi. Koronal kesitte üçgen kondil başı şeklinin görülme oranı \% 31.3 olarak belirlendi. İki yaş grubu arasında artiküler eminens eğimi ve yüksekliği açısından istatistiksel olarak anlamlı bir fark bulunamadi.

Sonuç: Kadın TMR hastalarında üçgen ve düz kondil başı tipleri en sık görülen kondil başı tipleri olarak saptanmıştır. AE eğiminin 18-30 yaş grubunda daha yüksek bulunmasına rağmen diğer grup ile arasında istatistiksel olarak anlamlı bir fark belirlenememiştir.

Keywords: Temporomandibular eklem rahatsızlıkları, konik ışınlı bilgisayarlı tomografi, artiküler eminens eğimi ve yüksekliği, kondil şekli.

\section{Cone Beam Ct Evaluations of Condyle Shape and Age-Related Associations of Articular Emınence Morphology in Female Tmd Patients}

Temporomandibular Joint (TMJ) is located between mandible and temporal bones and regarded as a complex articular system. Glenoid fossa is the superior and mandibular condylar process is the inferior bone part of the TMJ. Articular Eminence (AE) is a part of temporal bone on which the condylar process slides during the mandibular movements (1-3). The inclination of $\mathrm{AE}$ dictates the path 
of condylar movement and the degree of rotation of the disc over the condyle $(4,5)$ and the $\mathrm{AE}$ inclination varies between genders, healthy and TMD patients.

Temporomandibular disorder (TMD)is a collective term including clinical problems that involve the masticatory muscles, the temporomandibular joint (TMJ), and associated structures (6). This disorder comprises the second most common musculoskeletal pain condition following, low back pain. Its prevalence has been reported to have a wide range from 16.3 to $68 \%$ in the adolescences (7).

Women are more likely to develop TMD, probably due to the influence of behavioral, hormonal, anatomic, and psychosocial causes (8-10). Magnetic resonance imaging (MRI) has been accepted as a gold standard in the evaluation of displacement of articular disc and soft tissue structures. However, the diagnostic value of the MRI in the detection of bone structure of TMJ has been found limited $(12,13)$. Since the last decade, cone beam computed tomography (CBCT) has become widely used to detect the osseous structures of the TMJ $(12,14,15)$. Therefore, the aim of this study was to evaluate the condyle shape and assess the agerelated $\mathrm{AE}$ morphology in a group of female TMD patients using $\mathrm{CBCT}$.

\section{Methods}

The protocol of this retrospective study was approved by The Ethics Committee of Marmara University of Dentistry, Faculty (protocol no.2017/157).

The CBCT images of the TMJs of referring female TMD patients of Marmara University, Faculy of Dentistry were retrieved from the computer database of Department of Oral and Dentomaxillofacial Radiology from September 2013 to June 2017. The samples included the 64 TMJ images of 32 female TMD patients (18-45 years old) obtained by the same operator which utilized a large FOV flat panel detector 16x9 cm in size (Planmeca Promax 3D Mid; Planmeca Oy, Helsinki, Finland) with $36 \mathrm{sec}$. exposure time operating at $90 \mathrm{kV}, 14 \mathrm{~mA}$ with a reconstructed voxel size $0,40 \mathrm{~mm}^{3}$. The CBCT data sets were processed with reformatting software on the axial CBCT scans (Planmeca Romexis 3.83, Helsinki, Finland) and scans were directly assessed on a monitor screen (14 bit, 24-inch, NEC MD 242C2, $1920 \times$ 1200 resolution, USA). Patients with systemic rheumatoid disease, previously treated TMD, previous maxillofacial trauma, bimaxillary posterior edentulous arches and without maximum intercuspation and optimum image quality were excluded from the study.

The condyle shape was evaluated on the sagittal and coronal planes. The coronal plane was set parallel to the long axis of the condyle and the sagittal plane was set perpendicular to the coronal. The condyles were classified as "round", "oval" "triangular" and "flattened" both in the coronal and sagittal plane as described in previous studies $(5,16)$.

Inclination of $\mathrm{AE}$ was analyzed using with the best-fit and top-roof methods on the central sagittal slice and $\mathrm{AE}$ height was measured by the perpendicular distance between the lowest point of the $\mathrm{AE}$ and the highest point of the fossa on the same image (Figure 1) according to literature (3, 5, 1619). To obtain central sagittal slice, the section of condylar process which had the widest mediolateral diameter on axial slice was used for secondary reconstruction.
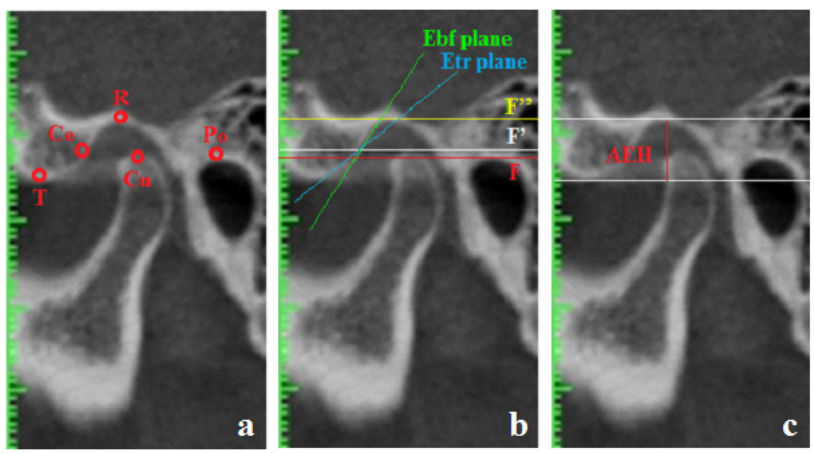

Figure 1 a. Reference points; Ce: the point at which the F' line cut the eminence posterior surface; $\mathrm{Cu}$ : the highest point of the condylar process; Po: porion (the highest point of auditory meatus); R: the highest point of the fossa; $\mathrm{T}$ : the lowest point of the articular eminence,

b. Reference planes; F: Frankfort horizontal plane; F' the parallel line to the $\mathrm{F}$ passing through the point $\mathrm{Cu}$; F": the parallel line to the $\mathrm{F}$ passing through the point $\mathrm{R}$ and measurements methods (The best-fit line method: the angle between Ebf and F plane; the top-roof line method; the angle between Etr and F plane) $(2,5)$,

c. AEH was measured by the perpendicular distance between the lowest point of the articular eminence and the highest point of the fossa $(5,20)$.

The points and planes for measurements in the present study were (Figure $1-\mathrm{a}, \mathrm{b})$;

Ce: the point at which the F' line cut the eminence posterior surface,

$\mathrm{Cu}$ : the highest point of the condylar process,

Po: porion (the highest point of auditory meatus)

R: the highest point of the fossa

T: the lowest point of the articular eminence

Ebf plane: the best-fit plane of the articular eminence inclination connecting the $\mathrm{Ce}$,

Etr plane: the plane passing through the points $\mathrm{Cu}$ and $\mathrm{R}$,

F: Frankfort horizontal plane; 
F': the parallel line to the $\mathrm{F}$ passing through the point $\mathrm{Cu}$ and F": the parallel line to the F passing through the point $\mathrm{R}$.

The AEI measurement methods were (Figure 1-b);

1. The best-fit line method; the angle between Ebf and F plane,

2. The top-roof line method; the angle between Etr and F plane $(2,5)$.

\section{Data Analysis}

Statistical Package for Social Sciences (SPSS, IBM, New York, USA) 21.0 software for Windows was used for the statistical analysis. Data were evaluated according to descriptive statistics, which are presented as frequencies (n) and percentages (\%). Mann Whitney $U$ test was used for the comparison of the quantitative data of two groups without normal distribution.

\section{Results}

The mean age of the patients was $28.22 \pm 8.64$ years. Table 1 shows the distribution of condyle shapes on sagittal and coronal CBCT sections. The most frequent condyle shape was flattened $(39,1 \%)$ on sagittal section and triangular $(43.8$ $\%$ ) on coronal. Round condyle shape was the least frequent type on both sections. Figure 2 shows the sagittal and coronal views of collaged condyle shapes. Measurements of Ebf and Etr angles analyzed according to best-fit and toproof methods respectively are shown in table 2 . When the TMD patients were evaluated as two different age groups, there were no statistically significant differences regarding the inclination and height of AE (Table 2).
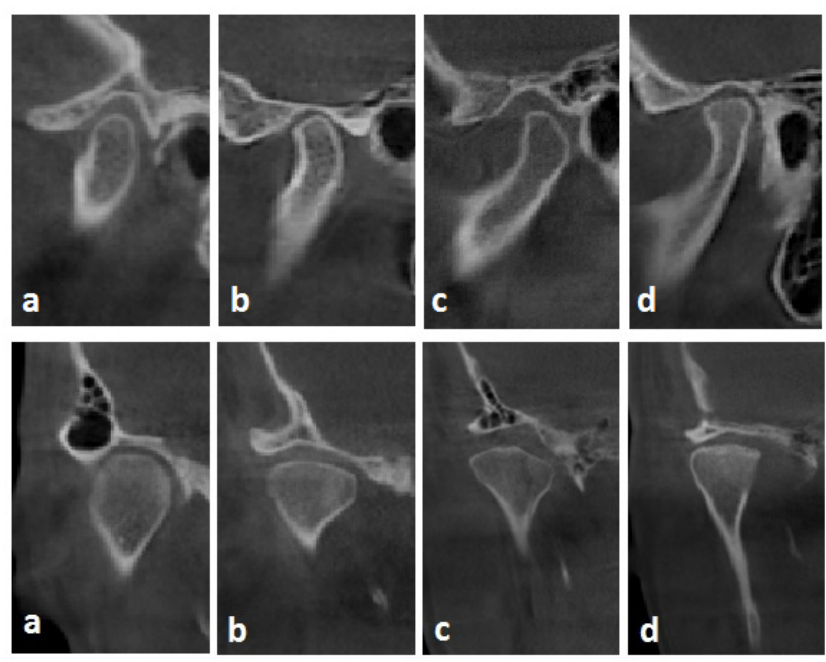

Figure 2 Condyle shapes on sagittal (above) and coronal (below) views: round (a), oval (b), triangular (c), flattened (d)

\section{Discussion}

Condyle is a rounded bone with a biconvex contour in the superior part and has an oval surface. The AE is an anatomical bone structure situated in front of glenoid fossa. Previous studies have shown that condylar morphology and the slope of posterior surface of AE may show changes by gender, age, facial type, occlusal forces/functions, malocclusions and particular anomalies/disorders $(3,13)$.

Previous epidemiological studies have reported a greater frequency and severity of female TMD patients than males. These differences have been mainly linked to psychological, behavioral, hormonal, and constitutional factors. Extensive literature was documented regarding the age distribution of female TMD patients suggested the link between TMD pathogenesis and the female hormonal axis. Women of childbearing age particularly have a tendency to have notable fluctuations in estrogen and progesterone levels and are reported to have a higher risk of developing TMD. Pain onset tends to have a peak in reproductive years with the highest prevalence occurring in females aged between 20 and 40-years. Moreover, females have higher rates of chronic anxiety and stress than men, and stress is one of the main predisposing factors for TMD $(8,9,21-24)$. In order to exclude above-mentioned factors, only the CBCT images of female TMD patients between 18-45 - year old were evaluated.

Morphological condyle changes have been found more frequent in adult to elderly populations due to agerelated degeneration (25-29). Pontual et al and Koyama et al evaluated the images of patients with clinical symptoms of TMJ and showed the altered condyle morphology and osseous bone changes $(9,14)$. In a previous study, Caglayan et al (16) observed a significant difference between the condyle and fossa shapes of TMD and control groups. Round condyle shape was more prominent in TMD groups whereas oval in the control group (16). Since all examined images of the present study were the CBCT sections of TMD patients, flattened and triangular condyles were found to be the most frequent condyle shapes whereas round condyle shape was examined only in one CBCT image in coronal and three in sagittal sections.

Previous researchers proposed that the $\mathrm{AE}$ might predispose to disc displacement. The shape of the $\mathrm{AE}$ is related to the development of TMJ disc displacement (7, 19, 28, 30-32). CBCT has been shown as an accurate and reliable method for the imaging of hard structures and linear measurements $(3,16,30)$. In the present study, CBCT was 
used for the measurements of AE and condyle morphology. The image of the $\mathrm{AE}$ in the central slice is regarded as the steepest part of the $\mathrm{AE}$ and the central slice of the condylar process was used for the true measurement of $\mathrm{AE}$ inclination in the present study $(3,30,33)$.

Kastavrias reported that the $\mathrm{AE}$ inclination completes approximately 90 to $94 \%$ of its growth by the age of 20 years (34). In order to assess the inclination of posterior slope of AE, the best-fit and top-roof methods were used in this study as in previous studies $(3,30)$.

Many studies showed the morphological changes of AE with advanced age $(28,29)$, whereas few studies found no correlation between advanced age and height or inclination of $\mathrm{AE}(3,30)$. Although the age interval of examined group was limited from 18 to 45 -year-old, no statistically significant age-related difference was found between 18 30 and 31-45-year-old groups regarding the measurements of $\mathrm{AE}$ and these findings were found to be consistent with Sümbüllü et al and İlgüy et al $(3,30)$.

The current study was limited by the gender and the number of images TMD patients. All CBCT images were taken for various dental purposes and condyle shape and inclination of AE were analyzed using them. Further research needs to be done to establish the condyle shape and $\mathrm{AE}$ inclination in broad age groups and larger TMD population.

\section{Acknowledgment}

The authors would like to thank Professor Dr. Gonca Mumcu (Marmara University, Faculty of Health Sciences, Department of Health Informatics and Technologies) for the statistical guidance in this study.

\section{Disclosure}

The authors claim to have no financial interest, directly or indirectly, in any entity that is commercially related to the products mentioned in this article.

Table 1: Distribution of condyle shapes on coronal and sagittal sections on CBCT

\begin{tabular}{lc|c|c|c}
\hline \multirow{2}{*}{$\begin{array}{l}\text { Condyle } \\
\text { shape }\end{array}$} & \multicolumn{2}{c}{ Sagittal Section } & \multicolumn{2}{c}{ Coronal Section } \\
\cline { 2 - 5 } & $\mathbf{n}$ & $\mathbf{\%}$ & $\mathbf{n}$ & $\mathbf{\%}$ \\
\hline Round & 3 & 4,7 & 1 & 1,6 \\
Oval & 16 & 25 & 15 & 23,4 \\
Triangle & 20 & 31,3 & 28 & 43,8 \\
Flattened & 25 & 39,1 & 20 & 31,3 \\
\hline Total & 64 & 100 & 64 & 100 \\
\hline
\end{tabular}

n, number of patients
Table 2: Associations of Ebf, Etr and AEH according to age groups

\begin{tabular}{llllll}
\hline & \multirow{2}{*}{ Age Groups } & & & \multicolumn{2}{c}{$\mathbf{p}$} \\
& & $\mathbf{n}$ & $\mathbf{m e a n}$. & $\mathbf{s d .}$ & $\mathbf{p}$ \\
\hline \multirow{2}{*}{ Ebf angle } & $18-30$ & 36 & 52,13 & 8,710 & \multirow{2}{*}{0,398} \\
& $31-45$ & 28 & 54,89 & 10,343 & \\
\multirow{2}{*}{ Etr angle } & $18-30$ & 36 & 34,35 & 5,368 & 0,607 \\
& $31-45$ & 28 & 35,92 & 6,943 & \\
\multirow{2}{*}{ AEH } & $18-30$ & 36 & 7,35 & 1,352 & 0 \\
& $31-45$ & 28 & 7,03 & 1,159 & \\
\hline
\end{tabular}

Mann Whitney U test, ${ }^{*} \mathrm{p}<0.05$

n, number of patients; sd, standart deviation; $\mathrm{AEH}$, articular eminence inclination

\section{References}

1. Pandis N, Karpac J, Trevino R, Williams B: A radiographic study of condyle position at various depths of cut in dry skulls with axially corrected lateral tomograms. Am J Orthod Dentofacial Orthop 1991;100:116-122.

2. Katsavrias EG: Changes in articular eminence inclination during the craniofacial growth period. Angle Orthod 2002;72:258-264.

3. Sümbüllü MA, Çağlayan F, Akgül HM, Yılmaz AB: Radiological examination of the articular eminence morphology using cone beam CT. Dentomaxillofac Radiol 2012;41:234-240.

4. Okeson JP. Management of Temporomandibular Disorders and Occlusion. 4th ed. St Louis, Mo: Mosby-Year Book; 1998:127-146.

5. Katsavrias EG: Morphology of the temporomandibular joint in subjects with class II division 2 malocclusions. Am J Orthod Dentofacial Orthop 2006;129:470-478.

6. Bae S, Park MS, Han JW, Kim YJ: Correlation between pain and degenerative bony changes on cone-beam computed tomography images of temporomandibular joints. Maxillofac Plast Reconstr Surg 2017;39(1):19.

7. Shahidi S, Salehi P, Abedi P, Dehbozorgi M, Hamedani S, Berahman N: Comparison of the Bony Changes of TMJ in Patients With and Without TMD Complaints Using CBCT. J Dent (Shiraz) 2018;19(2):142-149.

8. Warren MP, Fried JL: Temporomandibular disorders and hormones in womens. Cell Tiss Org 2001;169:187-192.

9. Koyama J, Nishiyama H, Hayashi T: Follow-up study of condylar bony changes using helical computed tomography in patients with temporomandibular disorder. Dentomaxillofac Radiol 2007;36:472-477.

10. Mazzetto MO, Rodrigues CA, Magri LV, Melchior MO, Paiva G. Severity of TMD related to age, sex and electromyographic analysis. Braz Dent J 2014;25(1):54-8.

11. Talmaceanu D, Lenghel LM, Bolog N, Hedesiu M, Buduru S, Rotar H, Baciut M, Baciut G: Imaging modalities for temporomandibular joint disorders: an update. Clujul Med. 2018;91(3):280-287.

12. Westesson PL, Katzberg RW, Tallents RH, Sanchez-Woodworth RE, Svensson SA: CT and MR of 
the temporomandibular joint: comparison with autopsy specimens. Am J Roentgenol 1987;148:1165-71.

13. Hedge S, Praveen BN, Shetty SR: Morphological and radiological variations of mandibular condyles in health and diseases: a systematic review. Dentistry 2013;3 (1):1-5.

14. Pontual ML, Freire JS, Barbosa JM, Fraza MA, Pontual A, Silveira MM: Evaluation of bone changes in the temporomandibular joint using cone beam CT. Dentomaxillofac Radiol 2012;41:24-29.

15. Borahan MO, Mayil M, Pekiner FN: Using cone beam computed tomography to examine the prevalence of condylar bony changes in a Turkish subpopulation. Niger J Clin Pract 2016;19(2):259-66.

16. Çağlayan F, Sümbüllü MA, Akgül HM: Associations between the articular eminence inclination and condylar bone changes, condylar movements, and condyle and fossa shapes. Oral Radiol 2014;30:84-91.

17. Katsavrias EG: The effect of mandibular protrusive (activator) appliances on articular eminence morphology. Angle Orthod 2003;73:647-653.

18. Yamada K, Tsuruta A, Hanada K, Hayashi T: Morphology of the articular eminence in temporomandibular joints and condylar bone change. J Oral Rehabil 2004;31:438-444.

19. Estomaguio GA, Yamada K, Ochi K, Hayashi T, Hanada K: Craniofacial morphology and inclination of the posterior slope of the articular eminence in female patients with and without condylar bone change. Cranio 2005;23:257-263.

20. Sato S, Kawamura K, Motegi K, Takashi K: Morphology of the mandibular fossa and the articular eminence in temporomandibular joints with anterior disk displacement. Int J Oral Maxillofac Surg 1996;25:236-238.

21. Siriwat PP, Jarabak JR: Malocclusion and facial morphology: is there a relationship? The Angle Orthodontist 1985;55(2):127-138.

22. Westesson PL, Eriksson L, Kurita K: Reliability of a negative clinical temporomandibular joint examination: prevalence of disk displacement in asymptomatic temporomandibular joints. Oral Surg Oral Med Oral Pathol. 1989;68:551-554.

23. Wiese M, Svensson P, Bakke M, List T, Hintze H, Petersson A, et al: Association between temporomandibular joint symptoms, signs, and clinical diagnosis using the RDC/ TMD and radiographic findings in temporomandibular joint tomograms. J Orofac Pain 2008;22:239-251.
24. Patil SR, Yadav N, Mousa MA, Alzwiri A, Kassab M, Sahu $\mathrm{R}$, Chuggani $\mathrm{S}$ : Role of female reproductive hormones estrogen and progesterone in temporomandibular disorders in female patients. J Oral Res Rev 2015;7:41-43.

25. Solberg WK, Hansson TL, Nordstrom B: The temporomandibular joint in young adults at autopsy: a morphologic classification and evaluation. J Oral Rehabil 1985;12 (4):303-321.

26. Wiberg B, Wänman A: Signs of osteoarthrosis of the temporomandibular joints in young patients: a clinical and radiographic study. Oral Surg Oral Med Oral Pathol Oral Radiol Endod 1998;86:158-164.

27. Widmalm SE, Westesson PL, Kim IK, Pereira FJ Jr, Lundh H, Tasaki MM: Temporomandibular joint pathosis related to sex, age, and dentition in autopsy material. Oral Surg Oral Med Oral Pathol 1994;78:416-425.

28. Kurita H, Ohtsuka A, Kobayashi H and Kurashina K: Flattening of the articular eminence correlates with progressive internal derangement of the temporomandibular joint. Dentomaxillofac Radiol 2000;29:277-279.

29. Sülün T, Cemgil T, Duc JM, Rammelsberg P, Jager L, Gernet W: Morphology of the mandibular fossa and inclination of the articular eminence in patients with internal derangement and in symptom-free volunteers. Oral Surg Oral Med Oral Pathol Oral Radiol Endod 2001;92:98-107.

30. İlgüy D, İlgüy M, Fişekçioğlu E, Dölekoğlu S, Ersan $\mathrm{N}$ : Articular eminence inclination, height, and condyle morphology on cone beam computed tomography. Sci World J DOİ: 10.1155/2014/761714

31. Özkan A, Altuğ HA, Sencimen M, Şenel B: Evaluation of articular eminence morphology and inclination in TMJ internal derangement patients with MRI. Int J Morphol 2012;30:740-744.

32. Sa SC, Melo SLS, Melo DP, Freitas DQ, Campos PSF: Relationship between articular eminence inclination and alterations of the mandibular condyle: a CBCT study. Braz Oral Res 2017;31:25.

33. Ichikawa J, Hara T, Tamatsu Y, Ide Y: Morphological changes in the internal structure of the articular eminence of the temporal bone during growth from deciduous to early mixed dentition. J Biomech 2007;40:3541-3547.

34. Katsavrias EG, Dibbets JM: The growth of articular eminence height during craniofacial growth period. Cranio 2001;19:13-20. 